Vol. $7, n^{\circ} 1 \mid 2003$

Varia

\title{
Martin Dinges, Fritz Sack (eds.), Unsichere Grosstädte? Vom Mittelalter bis zur Postmoderne
}

Konstanz UVK Universitätsverlag Konstanz GmbH, 2000, 396 pp., ISBN

3-87940-652-9

\section{Susanne Pohl}

\section{(2) OpenEdition}

\section{Journals}

Electronic version

URL: https://journals.openedition.org/chs/631

DOI: $10.4000 /$ chs.631

ISSN: 1663-4837

\section{Publisher}

Librairie Droz

\section{Printed version}

Date of publication: 1 July 2003

Number of pages: 146-150

ISBN: 2-600-00865-9

ISSN: 1422-0857

\section{Electronic reference}

Susanne Pohl, "Martin Dinges, Fritz Sack (eds.), Unsichere Grosstädte? Vom Mittelalter bis zur Postmoderne", Crime, Histoire \& Sociétés / Crime, History \& Societies [Online], Vol. 7, n 1 | 2003, Online since 24 February 2009, connection on 23 March 2022. URL: http://journals.openedition.org/chs/631 ; DOI: https://doi.org/10.4000/chs.631

This text was automatically generated on 23 March 2022.

(C) Droz 


\section{Martin Dinges, Fritz Sack (eds.), Unsichere Grosstädte? Vom Mittelalter bis zur Postmoderne}

Konstanz UVK Universitätsverlag Konstanz GmbH, 2000, 396 pp., ISBN

3-87940-652-9

Susanne Pohl

\section{REFERENCES}

Martin Dinges, Fritz Sack (eds.), Unsichere Grosstädte? Vom Mittelalter bis zur Postmoderne, Konstanz UVK Universitätsverlag Konstanz GmbH, 2000, 396 pp., ISBN 3-87940-652-9.

1 The collection of essays entitled «Unsichere Grossstädte» edited by Martin Dinges and Fritz Sack is an excellent contribution to the growing historiography of crime and society in Europe. In addition to an extensive introduction, the volume contains fifteen articles spanning the period from the Middle Ages to the end of the twentieth century. One article on early modern Rome, and two on American cities add a comparative perspective to the central focus on German cities. In their introduction, Dinges and Sack present an overview of the semantic history of the concept of «safety» from the Middle Ages to the present. The discussion of the safety discourse of current society is especially detailed. Their analysis provides a well-argued theoretical framework connecting the articles of the collection and offering provocative approaches to the question of safety in the cities.

In their discussion, Dinges and Sack acknowledge a debt to British and American historiography and argue that Germans would benefit from incorporating AngloAmerican research into their analyses of crime. The editors criticize how the majority of German historians and criminologists approach the question of safety through the analysis of statistics. The authors argue that these statistics reveal much about the institutions that produce them, but are not a reliable indicator of the actual safety of 
the city. Neither is the level of anxiety about safety an indicator for the objective danger to the public. Dinges and Sack believe that such anxiety seems actually to increase as a result of the measures taken to police the crime rate. Instead, they suggest that a concern with the social context that produces such anxiety is a more fruitful endeavor than the search for the perfect statistic. The production of an anxiety discourse about safety can be an effective strategy to promote a political or economic group, which can then pose as the protector of a social order under threat. Heightened anxiety and stronger growing clamor for stricter security measures have produced changes in social attitudes towards delinquents. Rather than locating the cause for a perceived increase in crime in social and economic factors in the environment of the transgressor, public consensus seeks to eliminate and eradicate the causes for unsafety. Dinges and Sack characterize this development as a shift from a welfare to a punitive state. This constitutes a reversal from the situation at the end of the late nineteenth century, when increasing concern for the social causes of delinquency promoted the origins of the welfare state. Minorities, such as poorer classes or immigrants, feel the brunt of this reversal since the late twentieth century, as society identifies them increasingly as «dangerous classes» that must be eliminated or marginalized rather than integrated through welfare programs. Drawing on Barbara Ehrenreich, Dinges and Sack identify the causes of this change as a middle class «fear of falling»: a fear resulting from a perceived threat posed by left wing movements with a more egalitarian social vision since the sixties. The postmodern state has turned from a liberal, or welfare state to a neoliberal or «revenge state» (revanchistischer Staat) where privileged groups look to draw rigid boundaries around themselves. Cities characterized by the coexistence of various social groups in a concentrated space are a perfect study ground to trace these social and political developments.

3 A striking feature of the volume is the tight connection between the various essays. The articles on postmodern society by Susanne Krassmann, Klaus Ronneberger and Herbert Beste revisit the theme of a shift towards a punitive state discussed in the editors' introduction. Krassmann uses Michel Foucault's concept of governmentality to explain this trend. The neoliberal state promotes an entrepreneurial mentality that challenges citizens to take full responsibility for their life choices. This strategy of «responsibilization» justifies aggressive measures in crime prevention and punishment. Ronneberger discusses the practical applications of neoliberal politics in his article on safety measures in present day German cities. He concentrates on current trends to create safe spaces within cities that attract middle class citizens for the pursuit of commercial and leisure activities. Urban planners employ strategic design and aggressive surveillance and expulsion strategies to exclude groups considered dangerous from shopping malls and themeparks. Herbert Beste's article focuses this discussion in a case study of late twentieth century Frankfurt. He argues that private security has become an important factor in the construction of a clean, safe city. The willingness of the police not only to cooperate with these agents but also to tolerate their often illegal methods erode the constitutional norms of civic liberty in the neoliberal city.

4 The specter of the American city with its often sharp divisions into safe zones (shopping malls, gated communities) and unsafe zones (ghettoization) looms in the background of these discussions. New York City under its mayor Rudolph Giuliani constitutes an especially important point of reference and comparison. Ronneberger, for example, sees in the politics of space in present-day German cities a gradual 
imitation of New York's «zero tolerance» policy, which to him is synonymous with a shift toward a controlling, punitive state. The last article in the collection by Henner Hess provides a detailed discussion of New York's «broken windows» politics. According to this theory, effective crime prevention starts with aggressive measures against disorder of any kind, even against apparently small transgressions such as graffiti spraying or fare dodging in the subway. Unlike other authors, Hess does not interpret these security measures as an indicator of a shift towards a repressive state, but as an effective way to reduce the crime rate. He does not share the editors' apprehension about statistics, but instead proves his point by detailing the development of the crime rate since the 1970's. The inclusion of different interpretations and methods to analyze current security measures should stimulate discussion and further research. It also makes the book excellent material for classroom use.

5 The articles on the premodern period provide interesting points of comparison to the postmodern security discussion. For example, the sources of anxiety about security differed. Peter Schuster's article on late medieval Constance as well as Gerd Schwerhoff's article on early modern Cologne argue that the inhabitants regarded their cities as islands of relative safety and trusted the force of its laws. According to Schuster, anxiety was located in a more unpredictable source: God's anger over citizens' immoral behavior that manifested itself in epidemic illnesses or foreign attacks. Unlike in modern cities, violence in the streets was not a major source of anxiety. Schuster stresses that theft constituted a far greater safety threat than violence. Schwerhoff points out that ritual fights in the defense of honor among middle class citizens were an accepted part of daily life and not harshly persecuted. Joachim Eibach's article on eighteenth century Frankfurt provides a bridge to the modern day security experience. He argues that middle class citizens no longer participated in violent street fights which were increasingly associated with lower class criminality.

Points of similarity with the postmodern period emerge as well, when several authors discuss strategies premodern cities used to create a sense of security. Schuster and Schwerhoff claim that cities tended to deflect anxiety onto groups considered dangerous, most often strangers, who then became victims of expulsion campaigns or exemplary punishments. With increased urbanization in the eighteenth century, Eibach shows that groups within the city, especially immigrants, became the focus of urban anxiety. The promotion of an anxiety discourse about safety could work to stabilize authority in premodern as well as in postmodern cities. Threats to urban safety were the recurring topics of edicts in eighteenth century Frankfurt. Eibach argues that the magistrate used these edicts to create a reality of unsafety even though Frankfurt was relatively safe in comparison with other European cities. The edicts justified aggressive security measures that legitimated the magistrate's authority.

7 The articles on postmodern cities stress the potential of the state to effectively supervise and control its citizens. They provide thought-provoking discussions of current trends, but lack an exploration of spaces within society that were less influenced by the politics of the neoliberal state or of strategies social actors can use to evade or partially compromise these politics. Given the weaker executive in the earlier epoch, the articles on the early modern period tend to focus more naturally on the compromises and negotiations that premodern security enforcement entailed. For example, Carl Hoffmann and Gerd Schwerhoff point out that early modern cities used a 
range of punitive and restitutive measures (such as private arbitration) to compensate for the weak executive.

8 Cooperation of the citizens was essential to early modern law enforcement. Carl Hoffmann and Andrea Bendlage present differing views of its success. Despite occasional resistance against the magistrate, Hoffmann argues that there was a general norm consensus amongst Augsburg's early modern citizens. Bendlage considers the relationship between citizens and law enforcement officials in a more problematic light. During the sixteenth century, the magistrate departed from an earlier emphasis on mediation and consensus and adopted more rigorous social disciplining measures. Citizens reacted to this change with an increasing marginalization of and resistance against city officials. Peter Blastenbrei's discussion of sixteenth century Rome highlights the differences in the relationship between citizens and magistrates in various early modern cities: cooperation with the police was a utopia in early modern Rome. The average Roman citizen distrusted the justice system due both to frequent policy changes from mild to harsh measures and the consistently lenient treatment of the nobility. As a consequence, Romans resented and resisted the police.

The effectiveness of police officials in enforcing security measures is also a topic in the essays on the modern period. Herbert Reinke shows how rapid urbanization in imperial Germany led to an increased anxiety about safety issues. As a result of repeated calls for modernization, the Berlin police divided into specialized units and adopted scientific methods to aid in the apprehension of delinquents.

10 The articles by Peter Lessmann-Faust and Patrick Wagner/Klaus Weinhauer provide examples of the practice of police operations in the Weimar Republic. Lessmann-Faust demonstrates that in the late 1920's the Prussian government was successful in promoting the influence of its police over the Reichswehr, which had been responsible for internal security until this time. Despite its increasing popularity, the efforts of the Prussian police to safeguard the streets against National-socialist violence was compromised by the increasing infiltration of the justice system with Nazi sympathizers. Patrick Wagner and Klaus Weinhauer discuss police attitudes towards underworld associations (Ringvereine) and wild youth gangs (Wilde Cliquen) around 1930. Enforcement of security measures against the Ringvereine was the result of a negotiation between police and these associations. On the one hand, members were loyal to the Ringvereine and resisted cooperation with the police. On the other hand, these groups were also able to enforce behavioral standards among their members and to guarantee a certain amount of order in the quarters that they dominated. This was acknowledged by the police who were therefore principally ready to tolerate their existence.

11 Most authors locate sources of security anxiety in class conflict. The articles by Gerd Schwerhoff, and Dietlind Huechtker introduce the category of gender, and Norbert Finzsch's article focuses on problems of race. These articles therefore demonstrate other fruitful directions that would stimulate a historiographical discourse about safety. Schwerhoff explores how the experience of security may have been different for men and for women in sixteenth-century Cologne, and he also raises the important question of domestic safety. Dietlind Huechtker demonstrates how the localization of a security anxiety in a perceived amorality of the lower classes had important repercussions for the politics of gender in early nineteenth-century Berlin. Prostitution was considered a particular danger as it provided a possible connection between lower 
class women and middle and upper class men; a contact that could infect the rest of society. This ideology justified aggressive police measures, which then had to be negotiated with the agenda of the Prussian Reforms seeking to safeguard the private sphere of citizens. Gender differential treatment was the result of this negotiation: while the private sphere of the male upper class client was safeguarded, the police aggressively supervised the female prostitute. Gender politics masked as security politics had consequences also for middle and upper class women, whose movements were restricted with the goal to "protect» them from contact with «dangerous» females. Norbert Finzsch's article on the police in nineteenth-century Washington D.C. introduces the category of race into the security discussion, as he analyzes how racism affected the police's treatment of African-Americans and Irish immigrants.

The security discussion in this volume could have been more comprehensive through a further exploration of gender, domestic safety/violence and race, as well as of a discussion of the differences between the security experience in city and countryside. As it is, this collection is incredibly cohesive, and can be read as a continuous history of the concept of safety/unsafety in the city from the medieval to the postmodern period.

\section{AUTHORS}

SUSANNE POHL

Cornell University, sp108@cornell.edu 